University of Nebraska - Lincoln

DigitalCommons@University of Nebraska - Lincoln

Faculty Papers and Publications in Animal

Science

Animal Science Department

April 1984

\title{
REPRODUCTIVE PERFORMANCE FOR FOUR BREEDS OF SWINE: CROSSBRED FEMALES AND PUREBRED AND CROSSBRED BOARS
}

D. S. Buchanan

Oklahoma State University, Stillwater

R. K. Johnson

Oklahoma State University, Stillwater, rjohnson5@unl.edu

Follow this and additional works at: https://digitalcommons.unl.edu/animalscifacpub

Part of the Animal Sciences Commons

Buchanan, D. S. and Johnson, R. K., "REPRODUCTIVE PERFORMANCE FOR FOUR BREEDS OF SWINE: CROSSBRED FEMALES AND PUREBRED AND CROSSBRED BOARS" (1984). Faculty Papers and Publications in Animal Science. 38.

https://digitalcommons.unl.edu/animalscifacpub/38

This Article is brought to you for free and open access by the Animal Science Department at DigitalCommons@University of Nebraska - Lincoln. It has been accepted for inclusion in Faculty Papers and Publications in Animal Science by an authorized administrator of DigitalCommons@University of Nebraska - Lincoln. 


\title{
REPRODUCTIVE PERFORMANCE FOR FOUR BREEDS OF SWINE: CROSSBRED FEMALES AND PUREBRED AND CROSSBRED BOARS ${ }^{1}$
}

\author{
D. S. Buchanan ${ }^{2}$ and R. K. Johnson ${ }^{3}$ \\ Oklahoma State University, Stillwater $\mathbf{7 4 0 7 8}$
}

\begin{abstract}
Summary
Matings and litters were studied involving all three-breed crosses (sired by purebred boars) and four-breed crosses (sired by crossbred boars) from the Duroc, Yorkshire, Landrace and Spotted breeds. There were 764 female mating records and 161 boars used over five sequential breeding seasons. A sample of pregnant gilts was slaughtered each season and the remainder were allowed to carry their litters to term so that 493 litters resulted. Crossbred and purebred boars and crossbred females were evaluated for their contributions to conception rate (first service and over an 8-wk breeding season), number of services/ conception, litter size and weight at birth, 21 and $42 \mathrm{~d}$ and survival rate to 21 and $42 \mathrm{~d}$. Crossbred boars had a $17.9 \%$ higher first service conception rate, a $5.3 \%$ higher breeding season conception rate and performed .11 fewer services/conception compared with purebred boars. There were no significant differences among the boar breeding groups for litter size, weight or survival rate. The six crossbred female groups (reciprocal crosses were combined) did not differ significantly in conception rate or number of services/ conception. There were significant differences in litter weight born and differences that approached significance $(P<.10)$ for litter size at $42 \mathrm{~d}$ and litter weight at $21 \mathrm{~d}$. Yorkshire-Landrace females had the largest litters
\end{abstract}

\footnotetext{
${ }^{1}$ Published as Paper No. 4302 Journal Series, Oklahoma Agr. Exp. Sta., Stillwater and a contribution from Regional Project NC-103, Genetic Improvement of Efficiency in the Production of Quality Pork.

${ }^{2}$ Anim. Sci. Dept. Oklahoma State Univ., Stillwater.

${ }^{3}$ Present address: Anim. Sci. Dept. Univ. of Nebraska, Lincoln 68583.

Received March 29, 1983.

Accepted March 30, 1984.
}

at birth, 21 and $42 \mathrm{~d}$ and the heaviest litters at 21 and $42 \mathrm{~d}$. The smallest litters at 21 and $42 \mathrm{~d}$ were from Yorkshire-Spotted females, and they also had the lighest weight litters at all three stages.

(Key Words: Crossbred Boars, Conception Rate, Sow Productivity.)

\section{Introduction}

Production efficiency in a commercial swine enterprise is partially dependent upon reproductive performance. There is considerable evidence that the choice of breeds and the structure of the breeding program have large impacts on reproductive efficiency (Johnson, 1980). The advantage of a crossbred female is clear, but there has been less research concerning the use of crossbred boars. Studies on young crossbred boars have generally shown an advantage in testis weight, mating behavior and conception rate (Hauser et al., 1952; Lishman et al., 1975; Wilson et al., 1977; Conlon and Kennedy, 1978; Neely et al., 1980), but more information is needed. There is also less information on the performance of the Landrace and Spotted breeds than for Durocs, Yorkshires or Hampshires.

This study was designed to evaluate the Duroc, Yorkshire, Landrace and Spotted breeds for producing crossbred females and to compare the reproductive performance of purebred and crossbred boars of these four breeds.

\section{Materials and Methods}

Purebred and two-breed cross litters involving the Duroc, Yorkshire, Spotted and Landrace breeds were produced at the Stillwater Swine Farm of Oklahoma State University during five farrowing seasons (fall and spring) beginning in the fall of 1976. Herd foundation and management were discussed previously (Hutchens et al., 1982). 
Unthrifty pigs were culled at weaning and one remaining male/litter was selected randomly to be castrated. Following completion of the finishing period, boars and gilts with obvious difficulty in walking were culled. All remaining gilts and a random sample of each type of purebred and crossbred boar were moved to the Southwest Livestock and Forage Research Station, El Reno, Oklahoma. There were representatives of each reciprocal cross but reciprocal crosses were combined for all subsequent analyses.

Crossbred females were hand-mated during an 8-wk breeding season to a purebred or crossbred boar from breeds unlike her own. Boars that showed no interest in mounting during three exposures to an estrous gilt were replaced with an alternate boar. Boars that mounted and mated were not replaced during the breeding period. Females that did not conceive to the matings during the first estrus expressed during the breeding period were remated to the same boar at each subsequent estrus. All females that did not conceive the first mating had an opportunity to express at least one more estrus. Several females were mated during each of three estrous periods, and on rare occasions females were mated during each of four estrous periods. Females were mated on the day that they were first observed in estrus and on each successive day that they would stand for a boar. Teaser boars were used to aid in estrous detection.

All possible three-breed cross (sired by purebred boars) and four-breed cross (sired by crossbred boars) litters were produced. This procedure was followed for five breeding seasons beginning in the spring of 1977 . Only gilts were mated during the first breeding season, but a random sample of sows was retained for each of the following seasons. For statistical analyses, all sows were included in a single parity group. There were 764 female mating records (556 gilts and 208 sows) and 161 boars. A sample of gilts was slaughtered before farrowing so that 493 litters resulted, and the slaughtered gilts were only used to evaluate conception rate and services/conception.

Litters were born in a farrowing house with individual farrowing crates with wood slatted floors. They were moved into concrete floor nursery pens 3 to $7 \mathrm{~d}$ postfarrowing. Creep feed was provided at about $14 \mathrm{~d}$, the male pigs were castrated at $21 \mathrm{~d}$ and the sows were removed from the litters at 42 d.

Traits Measured. Conception rate was determined for first service and for the 8-wk breeding season by scoring the matings that resulted in a pregnancy with a one and those that did not with a zero. The number of services required for each conception was also measured.

Litter size and weight were measured at birth, 21 and $42 \mathrm{~d}$. All fully formed pigs were counted and weighed at birth and all live pigs at 21 and $42 \mathrm{~d}$ were included. Survival rate to 21 and $42 \mathrm{~d}$ was the number of live pigs divided by the number of fully formed pigs at birth.

Data Analyses. Conception rate and number of services/conception were analyzed by ordinary least-squares. The model included the effects of season, parity, breed of dam, breed of sire nested within breed of dam, the interactions of breed of dam with parity, breed of dam with season and breed of sire within breed of dam with season and the partial regression on the female's weight at first mating. Separate regressions for gilts and sows were included because preliminary analyses indicated that the effect of female breeding weight was different for the two age classifications. Other two-way interactions were excluded based upon results of preliminary analyses $(\mathrm{P}>.20)$. These data were not normally distributed but satisfied the sample size requirements for analysis of discrete data with least-squares procedures (Harvey, 1982a). The effects of sires and dams were not included in the analyses, which may have led to downward bias in standard errors associated with the least-squares means for the breed groups.

The sums of squares for breed of sire within breed of data were divided into 12 single degree of freedom comparisons. For each of the six breeds of dam the crossbred boars were compared with the average of the purebred boars, and the two breeds of purebred boars were compared with each other.

Litter size and weight and survival rate were analyzed by gereralized least-squares procedures. Fixed effects included season, parity, breed of dam, breed of sire nested within breed of dam and the interaction of breed of dam with parity. The effect of sire within breed of sire and season was treated as random by adding the ratio of the error 
and sire components of variance. Then sires were absorbed. If the variance components are known, the solutions are generalized leastsquares estimates of the fixed effects (Harvey, 1982b). Because there were few estimates in the literature, variance components were estimated from these data. The dam's weight when she conceived was included as a single covariate. Other two-way interactions were tested in preliminary analyses and were excluded $(P>.20)$. There were some repeated records on dams that were not accounted for in the analyses. This may have led to some downward bias in the standard errors for the fixed effects.

\section{Results and Discussion}

Conception Rate and Services per Conception. Breeding season was a significant source of variation for first service conception rate, conception rate during the 8 -wk breeding season and the number of services/conception. The main effects of parity and the crossbred group of the female did not significantly affect these traits, but the breed group of the boar, nested within the crossbred group of the female, was a significant source of variation for all three traits. The interactions of breeding season with both crossbred group of female and breed group of boar within crossbred group of female significantly af fected both first service conception rate and number of services/conception. The interaction of parity with crossbred group of female was a significant source of variation for conception rate during the entire breeding season and approached significance $(P<.10)$ for first service conception rate.

TABLE 1. LEAST-SQUARES MEANS FOR REPRODUCTIVE PERFORMANCE OF PUREBRED AND CROSSBRED BOARS MATED TO CROSSBRED FEMALES

\begin{tabular}{|c|c|c|c|c|c|}
\hline \multirow[b]{2}{*}{ Crossbred group of female } & \multirow[b]{2}{*}{ Breed group of boar ${ }^{2}$} & \multirow[b]{2}{*}{ No. ${ }^{b}$} & \multicolumn{2}{|c|}{ Conception rate $(\%)$} & \multirow{2}{*}{$\begin{array}{l}\text { No. of services/ } \\
\text { conception }\end{array}$} \\
\hline & & & First service & Breeding season ${ }^{c}$ & \\
\hline Duroc-Yorkshire & $\begin{array}{l}\text { Landrace } \\
\text { Landrace-Spotted } \\
\text { Spotted } \\
\text { Average }\end{array}$ & $\begin{array}{r}32 \\
46 \\
37 \\
115\end{array}$ & $\begin{array}{l}64.1 \\
86.1 \\
67.5 \\
72.5\end{array}$ & $\begin{array}{l}83.4 \\
93.7 \\
93.0 \\
90.0\end{array}$ & $\begin{array}{l}1.27 \\
1.09 \\
1.33 \\
1.23\end{array}$ \\
\hline Duroc-Landrace & $\begin{array}{l}\text { Yorkshire } \\
\text { Yorkshire-Spotted } \\
\text { Spotted } \\
\text { Average }\end{array}$ & $\begin{array}{r}41 \\
58 \\
41 \\
140\end{array}$ & $\begin{array}{l}72.4 \\
81.5 \\
78.9 \\
77.6\end{array}$ & $\begin{array}{l}97.0 \\
96.3 \\
92.2 \\
95.2\end{array}$ & $\begin{array}{l}1.25 \\
1.16 \\
1.16 \\
1.19\end{array}$ \\
\hline Duroc-Spotted & $\begin{array}{l}\text { Yorkshire } \\
\text { Yorkshire-Landrace } \\
\text { Landrace } \\
\text { Average }\end{array}$ & $\begin{array}{r}40 \\
56 \\
42 \\
138\end{array}$ & $\begin{array}{l}74.8 \\
76.1 \\
60.4 \\
70.4\end{array}$ & $\begin{array}{l}95.1 \\
93.6 \\
90.0 \\
92.8\end{array}$ & $\begin{array}{l}1.28 \\
1.20 \\
1.36 \\
1.28\end{array}$ \\
\hline Yorkshire-Landrace & $\begin{array}{l}\text { Duroc } \\
\text { Duroc·Spotted } \\
\text { Spotted } \\
\quad \text { Average }\end{array}$ & $\begin{array}{r}35 \\
50 \\
34 \\
119\end{array}$ & $\begin{array}{l}71.2 \\
85.9 \\
83.2 \\
80.1\end{array}$ & $\begin{array}{l}87.3 \\
99.4 \\
89.2 \\
91.9\end{array}$ & $\begin{array}{l}1.20 \\
1.16 \\
1.09 \\
1.15\end{array}$ \\
\hline Yorkshire-Spotted & $\begin{array}{l}\text { Duroc } \\
\text { Duroc-Landrace } \\
\text { Landrace } \\
\quad \text { Average }\end{array}$ & $\begin{array}{r}38 \\
49 \\
37 \\
124\end{array}$ & $\begin{array}{l}66.9 \\
89.7 \\
78.4 \\
78.3\end{array}$ & $\begin{array}{l}96.5 \\
98.9 \\
95.5 \\
97.0\end{array}$ & $\begin{array}{l}1.30 \\
1.09 \\
1.23 \\
1.21\end{array}$ \\
\hline Landrace-Spotted & $\begin{array}{l}\text { Duroc } \\
\text { Duroc-Yorkshire } \\
\text { Yorkshire } \\
\text { Average }\end{array}$ & $\begin{array}{r}41 \\
50 \\
37 \\
128\end{array}$ & $\begin{array}{l}84.2 \\
92.2 \\
67.3 \\
81.2\end{array}$ & $\begin{array}{l}91.8 \\
96.0 \\
87.5 \\
91.8\end{array}$ & $\begin{array}{l}1.09 \\
1.05 \\
1.28 \\
1.14\end{array}$ \\
\hline $\begin{array}{l}\text { Standard error } \\
\text { (range) }\end{array}$ & $\begin{array}{l}\text { Individual breed group } \\
\text { Averages }\end{array}$ & & $\begin{array}{l}5.86-7.52 \\
3.89-4.11\end{array}$ & $\begin{array}{l}3.60-4.63 \\
2.39-2.71\end{array}$ & $\begin{array}{l}.059-.084 \\
.042-.047\end{array}$ \\
\hline
\end{tabular}

\footnotetext{
a.There were 15 to 18 boars in each breed group.

${ }^{b}$ Number of females available for breeding.

$c_{\text {Breeding season was } 8 \text { wk. }}$
} 
TABLE 2. LEAST-SQUARES MEANS FOR CONCEPTION RATES OF CROSSBRED GILTS AND SOWS

\begin{tabular}{|c|c|c|c|c|}
\hline \multirow{3}{*}{$\begin{array}{c}\text { Crossbred group } \\
\text { of female }\end{array}$} & \multicolumn{4}{|c|}{ Conception rate $(\%)^{2}$} \\
\hline & \multicolumn{2}{|c|}{ First service } & \multicolumn{2}{|c|}{ Breeding season ${ }^{b}$} \\
\hline & Gilt $^{\mathrm{c}}$ & Sow d & Gilt & Sow \\
\hline Duroc-Yorkshire & 84.2 & 60.9 & 97.1 & 83.0 \\
\hline Duroc-Landrace & 77.7 & 77.5 & 95.1 & 95.3 \\
\hline Duroc-Spotted & 80.1 & 60.7 & 93.3 & 92.3 \\
\hline Yorkshire-Landrace & 75.4 & 84.8 & 84.9 & 99.0 \\
\hline Yorkshire-Spotted & 80.0 & 76.7 & 93.4 & 100.0 \\
\hline Landrace-Spotted & 81.6 & 80.8 & 96.0 & 87.5 \\
\hline
\end{tabular}

${ }^{a}$ Standard errors ranged from 3.95 to 7.78 for first service and from 2.43 to 4.81 for breeding season conception rate.

${ }^{\mathrm{b}}$ Breeding season was 8 wk.

${ }^{c}$ First parity females.

${ }^{d}$ Any parity greater than or equal to second.

Breed group of boar and crossbred group of female least-squares means for conception rate and services/conception are presented in table 1 along with the number of attempted matings for each breed group combination. Differences among the female crossbred groups were not significant for any of the traits. The ranges for the female groups were 70.4 (Duroc-Spotted) to $81.2 \%$ (Landrace-Spotted) for first service conception rate, 90.0 (DurocYorkshire) to $97.0 \%$ (Yorkshire-Spotted) for overall conception rate and 1.14 (LandraceSpotted) to 1.28 (Duroc-Spotted) for services/ conception. Other studies also have not found significant conception rate differences among types of crossbred females (Holtmann et al., 1975; Drewry, 1980).
The interaction of breeding season with crossbred group of the female was significant for both first service conception rate and number of services/conception. Examination of the means revealed no consistent pattern. The ranking of the female crossbred groups varied widely from season-to-season. The interaction of parity with crossbred group of the female (table 2) resulted from DurocYorkshire and Duroc-Spotted gilts having substantially higher first service conception rates than the same groups as sows, while Yorkshire-Landrace gilts had lower first service conception rates than Yorkshire-Landrace sows. Yorkshire-Landrace females also had lower conception rates for the entire breeding season as gilts while Duroc-Yorkshire and Landrace-Spotted females had lower conception rates as sows.

Comparisons among breed groups of boar for first service conception rate are shown in table 3. Crossbred boars were superior to the average of the constituent purebreds for first service conception rate in all six comparisons. The advantage was significant for Landrace-Spotted, Duroc-Landrace and Duroc-Yorkshire crossbred boars. The average paternal or boar heterosis for first service conception rate was $17.9 \%$. Two of the comparisons between purebred boars approached significance $(\mathrm{P}<.10)$. Landrace boars were superior to Yorkshire boars when mated to Duroc-Spotted females (74.8 vs $60.4 \%$ ) and Yorkshire boars were superior to Duroc boars when mated to Landrace-Spotted females (84.2 vs $67.3 \%)$. Conversely, the direct comparison involving Duroc and Landrace boars favored the Duroc, although the difference was not significant.

TABLE 3. COMPARISONS AMONG SIRE BREED GROUPS FOR FIRST SERVICE CONCEPTION RATE PERCENTAGE

\begin{tabular}{|c|c|c|c|}
\hline \multirow{2}{*}{$\frac{\text { Crossbred group of female }}{\text { Duroc-Yorkshire }}$} & Crossbred-purebred $^{\mathrm{a}}$ & \multicolumn{2}{|c|}{ Purebred 1 -purebred 2} \\
\hline & LS $-1 / 2(L+S) \quad 20.3 \pm 7.6^{* *}$ & $\mathbf{L}-\mathbf{S}$ & $3.4 \pm 9.6$ \\
\hline Duroc-Landrace & $\mathrm{YS}-1 / 2(\mathrm{Y}+\mathrm{S}) \quad 5.8 \pm 6.7$ & $\mathbf{Y}-\mathbf{S}$ & $6.5 \pm 8.6$ \\
\hline Duroc-Spotted & $\mathrm{YL}-1 / 2(\mathrm{Y}+\mathrm{L}) \quad 8.5 \pm 6.8$ & $\mathbf{Y}-\mathbf{L}$ & $-14.3 \pm 8.7^{\dagger}$ \\
\hline Yorkshire-Landrace & $\mathrm{DS}-1 / 2(\mathrm{D}+\mathrm{S}) \quad 8.7 \pm 7.4$ & $\mathbf{D}-\bar{S}$ & $11.9 \pm 9.9$ \\
\hline Yorkshire-Spotted & $\mathrm{DL}-1 / 2(\mathrm{D}+\mathrm{L}) 17.0 \pm 7.3^{*}$ & D-L & $11.5 \pm 9.2$ \\
\hline Landrace-Spotted & DY $-1 / 2(D+Y) 16.5 \pm 7.1$ & $\mathbf{D}-\mathbf{Y}$ & $-16.8 \pm 8.8^{\dagger}$ \\
\hline
\end{tabular}

\footnotetext{
${ }^{\mathbf{a}} \mathbf{L}=$ Landrace, $\mathbf{S}=$ Spotted; $\mathbf{Y}=$ Yorkshire, $\mathbf{D}=$ Duroc

${ }^{\dagger} \mathbf{P}<10$.

* $\mathbf{P}<.05$.

${ }^{* *} \mathrm{P}<.01$.
} 
TABLE 4. COMPARISONS AMONG SIRE BREED GROUPS FOR CONCEPTION RATE PERCENTAGE DURING AN 8-WEEK BREEDING SEASON

\begin{tabular}{|c|c|c|c|c|}
\hline \multirow{2}{*}{$\frac{\text { Crossbred group of female }}{\text { Duroc-Yorkshire }}$} & \multicolumn{2}{|c|}{ Crossbred-purebred ${ }^{2}$} & \multicolumn{2}{|c|}{ Purebred 1-purebred 2} \\
\hline & $\mathrm{LS}-1 / 2(\mathrm{~L}+\mathrm{S})$ & $5.5 \pm 4.7$ & $\mathbf{L}-\mathbf{S}$ & $9.6 \pm 5.9^{t}$ \\
\hline Duroc-Landrace & $Y S-1 / 2(Y+S)$ & $1.7 \pm 4.2$ & $\mathbf{Y}-\mathbf{S}$ & $-4.7 \pm 5.3$ \\
\hline Duroc-Spotted & $Y L-1 / 2(Y+L)$ & $1.2 \pm 4.2$ & $\mathbf{Y}-\mathbf{L}$ & $-5.5 \pm 5.3$ \\
\hline Yorkshire-Landrace & $\mathrm{DS}-1 / 2(\mathrm{D}+\mathrm{S})$ & $11.1 \pm 4.6^{*}$ & $\mathrm{D}-\mathrm{S}$ & $1.9 \pm 6.1$ \\
\hline Yorkshire-Spotted & $\mathrm{DL}-1 / 2(\mathrm{D}+\mathrm{L})$ & $2.9 \pm 4.5$ & $\bar{D}-\mathrm{L}$ & $-1.0 \pm 5.7$ \\
\hline Landrace-Spotted & $D Y-1 / 2(D+Y)$ & $6.4 \pm 4.4$ & $\bar{D}-\mathbf{Y}$ & $-4.3 \pm 5.4$ \\
\hline
\end{tabular}

${ }^{a_{L}}=$ Landrace, $S=$ Spotted, $Y=$ Yorkshire, $D=$ Duroc.

${ }^{\dagger} \mathbf{P}<10$.

* $\mathrm{P}<.05$.

The advantage in conception rate from using crossbred boars was less when the entire 8-wk breeding season was evaluated (table 4). Duroc-Spotted boars were significantly superior to Duroc and Spotted purebreds, and the average heterosis for all breeds was $5.33 \%$. Despite the reduction, the crossbred boars were superior to the average of the purebred boars in all six comparisons. Use of Landrace boars resulted in a higher conception rate compared with each of the other breeds, although differences were not significant.

The number of services/conception provides an additional measure of a boar's breeding efficiency. Certain females may be unable or very slow to conceive due to problems that are unrelated to the boar. These could greatly affect the average conception rate, but would have a smaller effect on the number of services/conception. Except for the comparison involving Duroc, Spotted and Duroc-Spotted boars, the crossbred vs pure- bred boar comparisons (table 5) were very similar to the corresponding comparisons for first service conception rate. Crossbred boars required .11 fewer services/conception than purebred boars. Duroc-Spotted boars were superior to the purebreds for first service conception rate but were slightly inferior for number of services/conception.

The interaction of breeding season and breed group of boar within crossbred group of female was significant for first service conception rate and number of services/conception. Despite the significant interaction, the crossbred boars were superior to the average of the purebred boars for 26 of the 30 breeding season by crossbred group of female combinations. There were numerous changes in rank between the two breeds of purebred boars and changes in magnitude of the crossbred boar advantage.

The advantage in conception rate when crossbred boars were used in natural service agreed with other reports (Wilson et al., 1977;

TABLE 5. COMPARISONS AMONG BREED GROUPS OF SIRE FOR NUMBER OF SERVICES PER CONCEPTION

\begin{tabular}{llcr}
\hline \hline Crossbred group of female & Crossbred-purebred & Purebred 1-purebred 2 \\
\hline Duroc-Yorkshire & LS-1/2(L+S) $-.211 \pm .08^{* *}$ & $\mathrm{~L}-\mathrm{S}$ & $.063 \pm .10$ \\
Duroc-Landrace & $\mathrm{YS}-1 / 2(\mathrm{Y}+\mathrm{S})-.042 \pm .07$ & $\mathrm{Y}-\mathrm{S}$ & $-.097 \pm .09$ \\
Duroc-Spotted & $\mathrm{YL}-1 / 2(\mathrm{Y}+\mathrm{L})-.124 \pm .07^{\dagger}$ & $\mathrm{Y}-\mathrm{L}$ & $.081 \pm .09$ \\
Yorkshire-Landrace & $\mathrm{DS}-1 / 2(\mathrm{D}+\mathrm{S}) .019 \pm .08$ & $\mathrm{D}-\mathrm{S}-.076 \pm .10$ \\
Yorkshire-Spotted & $\mathrm{DL}-1 / 2(\mathrm{D}+\mathrm{L})-.179 \pm .08$ & $\mathrm{D}-\mathrm{L}-.076 \pm .10$ \\
Landrace-Spotted & $\mathrm{DY}-1 / 2(\mathrm{D}+\mathrm{Y})-.140 \pm .07^{\dagger}$ & $\mathrm{D}-\mathrm{Y}$ & $.193 \pm .09 *$ \\
\hline
\end{tabular}

${ }^{\mathrm{a}} \mathrm{L}=$ Landrace, $\mathrm{S}=$ Spotted, $\mathrm{Y}=$ Yorkshire, $\mathrm{D}=$ Duroc.

$t_{P<.10 .}$

$* \mathrm{P}<05$.

${ }^{* *} \mathrm{P}<.01$ 
Anderson et al., 1981). Conlon and Kennedy (1978) used semen from purebred and crossbred boars to artificially breed gilts and showed a very small crossbred boar advantage in conception rate. The advantage in first service conception rate may have resulted from the crossbred boars being more mature sexually despite being similar in actual age. If so, the reduced advantage for the entire breeding season is not surprising because the purebred boars would have matured during the 8 wk of breeding. More advanced sexual maturity (measured by testis weight and sperm numbers) in crossbred boars has been demonstrated by several studies (Hauser et al., 1952; Wilson et al., 1977; Fent, 1980; Neely et al., 1980).

Litter Size, Litter Weight and Survival Rate. Breeding season was a significant source of variation for litter weight at birth, 21 and $42 \mathrm{~d}$. Parity had a significant effect on all litter size, weight and survival traits measured except litter size at birth. Crossbred group of the dam affected $(P<.05)$ litter weight at birth and had an effect that approached significance $(\mathrm{P}<.10)$ for litter size at $42 \mathrm{~d}$ and litter weight at $21 \mathrm{~d}$. Breed group of the sire, nested within crossbred group of the dam, did not significantly affect any of the litter traits. The interaction of parity with crossbred group of the dam had a significant effect only on litter size at birth.

The crossbred group generalized leastsquares means for litter size and the number of litters in each group are shown in table 6. Yorkshire-Landrace females had the largest litters at all three stages $(10.34,8.39,8.30$ at birth, 21 and $42 \mathrm{~d}$, respectively) while

TABLE 6. GENERALIZED LEAST-SQUARES MEANS FOR LITTER SIZE FROM CROSSBRED FEMALES MATED TO PUREBRED AND CROSSBRED BOARS

\begin{tabular}{|c|c|c|c|c|c|}
\hline \multirow[b]{2}{*}{ Crossbred group of female } & \multirow[b]{2}{*}{ Breed group of boar ${ }^{2}$} & \multirow[b]{2}{*}{ No. ${ }^{b}$} & \multicolumn{3}{|c|}{ Litter size } \\
\hline & & & Birth $^{c}$ & $21 d^{d}$ & $42 d^{d}$ \\
\hline Duroc-Yorkshire & $\begin{array}{l}\text { Landrace } \\
\text { Landrace-Spotted } \\
\text { Spotted } \\
\quad \text { Average }\end{array}$ & $\begin{array}{l}20 \\
29 \\
27 \\
76\end{array}$ & $\begin{array}{r}10.34 \\
10.17 \\
9.88 \\
10.13\end{array}$ & $\begin{array}{l}8.03 \\
7.96 \\
7.71 \\
7.90\end{array}$ & $\begin{array}{l}7.83 \\
7.85 \\
7.56 \\
7.74\end{array}$ \\
\hline Duroc-Landrace & $\begin{array}{l}\text { Yorkshire } \\
\text { Yorkshire-Spotted } \\
\text { Spotted } \\
\text { Average }\end{array}$ & $\begin{array}{l}29 \\
37 \\
27 \\
93\end{array}$ & $\begin{array}{r}10.52 \\
10.12 \\
9.88 \\
10.18\end{array}$ & $\begin{array}{l}8.20 \\
8.07 \\
8.10 \\
8.13\end{array}$ & $\begin{array}{l}7.94 \\
7.94 \\
7.88 \\
7.92\end{array}$ \\
\hline Duroc-Spotted & $\begin{array}{l}\text { Yorkshire } \\
\text { Yorkshire-Landrace } \\
\text { Landrace } \\
\text { Average }\end{array}$ & $\begin{array}{l}25 \\
34 \\
25 \\
84\end{array}$ & $\begin{array}{r}9.22 \\
10.52 \\
10.39 \\
10.04\end{array}$ & $\begin{array}{l}6.87 \\
7.73 \\
8.19 \\
7.60\end{array}$ & $\begin{array}{l}6.84 \\
7.67 \\
8.09 \\
7.53\end{array}$ \\
\hline Yorkshire-Landrace & $\begin{array}{l}\text { Duroc } \\
\text { Duroc-Spotted } \\
\text { Spotted } \\
\quad \text { Average }\end{array}$ & $\begin{array}{l}22 \\
34 \\
23 \\
79\end{array}$ & $\begin{array}{l}10.50 \\
10.31 \\
10.23 \\
10.34\end{array}$ & $\begin{array}{l}8.45 \\
8.16 \\
8.57 \\
8.39\end{array}$ & $\begin{array}{l}8.32 \\
8.10 \\
8.48 \\
8.30\end{array}$ \\
\hline Yorkshire-Spotted & $\begin{array}{l}\text { Duroc } \\
\text { Duroc-Landrace } \\
\text { Landrace } \\
\quad \text { Average }\end{array}$ & $\begin{array}{l}26 \\
31 \\
23 \\
80\end{array}$ & $\begin{array}{r}9.33 \\
10.25 \\
10.00 \\
9.86\end{array}$ & $\begin{array}{l}7.34 \\
7.01 \\
7.75 \\
7.37\end{array}$ & $\begin{array}{l}7.11 \\
6.77 \\
7.51 \\
7.13\end{array}$ \\
\hline Landrace-Spotted & $\begin{array}{l}\text { Duroc } \\
\text { Duroc-Yorkshire } \\
\text { Yorkshire } \\
\quad \text { Average }\end{array}$ & $\begin{array}{l}29 \\
29 \\
23 \\
81\end{array}$ & $\begin{array}{l}9.88 \\
9.65 \\
9.88 \\
9.80\end{array}$ & $\begin{array}{l}8.09 \\
7.63 \\
8.02 \\
7.91\end{array}$ & $\begin{array}{l}7.84 \\
7.44 \\
7.87 \\
7.72\end{array}$ \\
\hline $\begin{array}{l}\text { Standard error } \\
\text { (range) }\end{array}$ & $\begin{array}{l}\text { Individual breed groups } \\
\text { Averages }\end{array}$ & & $\begin{array}{l}.47-.59 \\
.31-.37\end{array}$ & $\begin{array}{l}.40-.55 \\
.28-.31\end{array}$ & $\begin{array}{l}.40-.55 \\
.28-.34\end{array}$ \\
\hline
\end{tabular}

\footnotetext{
a There were 15 to 18 boars in each breed group.

${ }^{b}$ Number of litters.

${ }^{c}$ Number of fully formed pigs.

$d_{\text {Number of live pigs. }}$
} 
TABLE 7. GENERALIZED LEAST-SQUARES MEANS FOR LITTER SIZE AT BIRTH OF CROSSBRED GILTS AND SOWS

\begin{tabular}{lrr}
\hline \hline & \multicolumn{2}{c}{ Litter size at birth } \\
\cline { 2 - 3 } Female crossbred group & Gilt & Sow \\
\hline Duroc-Yorkshire & 10.56 & 9.69 \\
Duroc-Landrace & 9.50 & 10.85 \\
Duroc-Spotted & 9.60 & 10.49 \\
Yorkshire-Landrace & 10.64 & 10.04 \\
Yorkshire-Spotted & 10.00 & 9.73 \\
Landrace-Spotted & 9.61 & 10.00
\end{tabular}

${ }^{a}$ Standard errors ranged from .361 to .542 .

Landrace-Spotted females had the smallest litters at birth (9.80 pigs) and YorkshireSpotted females had the smallest litters at 21 and $42 \mathrm{~d}$ ( 7.37 and 7.13 pigs). The interaction of parity with crossbred group of dam was significant for litter size at birth (table 7). This interaction resulted from gilt litters being larger from Duroc-Yorkshire, Yorkshire-Landrace and Yorkshire-Spotted females while sow litters were larger from the other three breed groups. Among gilts, Yorkshire-Landrace females had the largest litters (10.64 pigs) and Duroc-Landrace females had the smallest litters ( 9.50 pigs). However, for sows, the largest litters were from DurocLandrace females ( 10.85 pigs) and the smallest were from Duroc-Yorkshire females (9.69 pigs).

Crossbred boars sired litters that were, on the average, .17 pigs larger at birth, .18 pigs smaller at $21 \mathrm{~d}$ and .14 pigs smaller at $42 \mathrm{~d}$ than litters sired by the corresponding purebred boars. These differences did not approach significance ( $P>.40$ ).

Crossbred group generalized least-squares means for litter weight traits are shown in table 8. Duroc-Landrace females had the heaviest litters at birth $(14.6 \mathrm{~kg})$. Litters from Yorkshire-Landrace females were the

TABLE 8. GENERALIZED LEAST-SQUARES MEANS FOR LITTER WEIGHT FROM CROSSBRED FEMALES MATED TO PUREBRED AND CROSSBRED BOARS

\begin{tabular}{|c|c|c|c|c|}
\hline \multirow[b]{2}{*}{ Crossbred group of female } & \multirow[b]{2}{*}{ Breed group of boar } & \multicolumn{3}{|c|}{ Litter weight $(\mathrm{kg})$} \\
\hline & & Birth $^{2}$ & $21 \mathrm{~d}^{\mathrm{b}}$ & $42 \mathrm{~d}^{\mathrm{b}}$ \\
\hline Duroc-Yorkshire & $\begin{array}{l}\text { Landrace } \\
\text { Landrace-Spotted } \\
\text { Spotted } \\
\quad \text { Average }\end{array}$ & $\begin{array}{l}14.68 \\
14.21 \\
13.96 \\
14.28\end{array}$ & $\begin{array}{l}43.01 \\
41.13 \\
39.88 \\
41.34\end{array}$ & $\begin{array}{l}94.68 \\
89.00 \\
85.40 \\
89.70\end{array}$ \\
\hline Duroc-Landrace & $\begin{array}{l}\text { Yorkshire } \\
\text { Yorkshire-Spotted } \\
\text { Spotted } \\
\text { Average }\end{array}$ & $\begin{array}{l}14.55 \\
15.03 \\
14.35 \\
14.64\end{array}$ & $\begin{array}{l}40.23 \\
42.35 \\
42.94 \\
41.84\end{array}$ & $\begin{array}{l}87.47 \\
92.66 \\
91.64 \\
90.59\end{array}$ \\
\hline Duroc-Spotted & $\begin{array}{l}\text { Yorkshire } \\
\text { Yorkshire-Landrace } \\
\text { Landrace } \\
\text { Average }\end{array}$ & $\begin{array}{l}13.25 \\
14.52 \\
14.71 \\
14.16\end{array}$ & $\begin{array}{l}37.18 \\
40.16 \\
42.90 \\
40.08\end{array}$ & $\begin{array}{l}82.15 \\
87.86 \\
96.77 \\
88.93\end{array}$ \\
\hline Yorkshire-Landrace & $\begin{array}{l}\text { Duroc } \\
\text { Duroc-Spotted } \\
\text { Spotted } \\
\quad \text { Average }\end{array}$ & $\begin{array}{l}14.54 \\
13.14 \\
13.99 \\
13.89\end{array}$ & $\begin{array}{l}44.89 \\
40.93 \\
44.04 \\
43.29\end{array}$ & $\begin{array}{l}93.69 \\
89.17 \\
95.86 \\
92.91\end{array}$ \\
\hline Yorkshire-Spotted & $\begin{array}{l}\text { Duroc } \\
\text { Duroc-Landrace } \\
\text { Landrace } \\
\quad \text { Average }\end{array}$ & $\begin{array}{l}11.98 \\
13.28 \\
13.20 \\
12.82\end{array}$ & $\begin{array}{l}38.89 \\
36.57 \\
39.96 \\
38.47\end{array}$ & $\begin{array}{l}84.35 \\
76.50 \\
86.20 \\
82.35\end{array}$ \\
\hline Landrace-Spotted & $\begin{array}{l}\text { Duroc } \\
\text { Duroc-Yorkshire } \\
\text { Yorkshire } \\
\text { Average }\end{array}$ & $\begin{array}{l}13.67 \\
13.55 \\
14.52 \\
13.91\end{array}$ & $\begin{array}{l}42.12 \\
41.89 \\
42.24 \\
42.75\end{array}$ & $\begin{array}{l}89.01 \\
86.79 \\
96.85 \\
90.88\end{array}$ \\
\hline $\begin{array}{l}\text { Standard error } \\
\text { (range) }\end{array}$ & $\begin{array}{l}\text { Individual breed groups } \\
\text { Averages }\end{array}$ & $\begin{array}{l}.55-.75 \\
.38-.46\end{array}$ & $\begin{array}{l}1.84-2.54 \\
1.32-1.60\end{array}$ & $\begin{array}{l}4.02-5.48 \\
2.77-3.36\end{array}$ \\
\hline
\end{tabular}

\footnotetext{
${ }^{\mathrm{a}}$ Weight of all fully formed pigs.

$b_{\text {Weight of all live pigs. }}$
} 
heaviest at $21(43.3 \mathrm{~kg})$ and $42 \mathrm{~d}(92.9 \mathrm{~kg})$. Yorkshire-Spotted females had the lighest weight litters at all three stages $(12.8,38.5$ and $82.4 \mathrm{~kg}$ at birth, $21 \mathrm{~d}$ and $42 \mathrm{~d}$, respectively). Litters sired by crossbred boars were $.01 \mathrm{~kg}$ heavier at birth $(\mathrm{P}>.90)$ and 1.19 $(\mathrm{P}>.20)$ and $3.34 \mathrm{~kg}(\mathrm{P}>.10)$ lighter weight at 21 and $42 \mathrm{~d}$, respectively.

Litters from the three female crossbred groups that were one-half Landrace had slightly higher survival rates (table 9) than those from other female breeding groups $(81.7$ vs $78.0 \%$ at $21 \mathrm{~d}$ and 80.1 vs $76.5 \%$ at $42 \mathrm{~d}$ ). These differences were not significant. Litters sired by crossbred boars had 2.7 and $2.4 \%$ lower $(\mathbf{P}>.10)$ survival rates to 21 and $42 \mathrm{~d}$, respectively, than litters by purebred boars.

These results generally favor YorkshireLandrace females for traits associated with sow productivity. Other crossbred females that were one-half Landrace also performed well, particularly in traits measured at 21 and $42 \mathrm{~d}$. This is in partial agreement with other studies that included crossbred females that were one-half Landrace. Holtmann et al. (1975) reported increased litter size at birth and $21 \mathrm{~d}$ and heavier litters at $21 \mathrm{~d}$ from Yorkshire-Landrace females when they were compared with Duroc-Yorkshire and DurocYorkshire females. Drewry (1980) showed an advantage in litter size and weight at both birth and $35 \mathrm{~d}$ for litters of Duroc-Yorkshire females when compared with YorkshireLandrace females. Kuhlers et al. (1981) compared the same two female crossbred groups and reported no significant differences in litter size, but pigs out of Duroc-Yorkshire dams were heavier. In another study, Kuhlers et al. (1982) found no significant differences in litter size when Duroc-Landrace and Spotted-Landrace females were compared, but Duroc-Landrace females had heavier litters at both 21 and 42 d.

Litter performance was relatively unaffected by the breed group of the sire. No change in litter size, when crossbred boars were used, has been reported elsewhere (Lishman et al.,

TABLE 9. GENERALIZED LEAST-SQUARES MEANS FOR SURVIVAL RATE OF LITTERS FROM CROSSBRED FEMALES MATED TO PUREBED AND CROSSBRED BOARS

\begin{tabular}{|c|c|c|c|}
\hline \multirow[b]{2}{*}{ Crossbred group of female } & \multirow[b]{2}{*}{ Breed group of boar } & \multicolumn{2}{|c|}{ Survival rate (\%) } \\
\hline & & $21 \mathrm{~d}$ & $42 d$ \\
\hline Duroc-Yorkshire & $\begin{array}{l}\text { Landrace } \\
\text { Landrace-Spotted } \\
\text { Spotted } \\
\quad \text { Average }\end{array}$ & $\begin{array}{l}79.62 \\
80.45 \\
78.70 \\
79.59\end{array}$ & $\begin{array}{l}77.81 \\
79.43 \\
77.28 \\
78.19\end{array}$ \\
\hline Duroc-Landrace & $\begin{array}{l}\text { Yorkshire } \\
\text { Yorkshire-Spotted } \\
\text { Spotted } \\
\text { Average }\end{array}$ & $\begin{array}{l}80.32 \\
80.45 \\
83.90 \\
81.56\end{array}$ & $\begin{array}{l}78.01 \\
79.39 \\
81.73 \\
79.71\end{array}$ \\
\hline Duroc-Spotted & $\begin{array}{l}\text { Yorkshire } \\
\text { Yorkshire-Landrace } \\
\text { Landrace } \\
\text { Average }\end{array}$ & $\begin{array}{l}77.20 \\
75.29 \\
80.88 \\
77.52\end{array}$ & $\begin{array}{l}76.84 \\
74.50 \\
79.33 \\
76.89\end{array}$ \\
\hline Yorkshire-Landrace & $\begin{array}{l}\text { Duroc } \\
\text { Duroc-Spotted } \\
\text { Spotted } \\
\quad \text { Average }\end{array}$ & $\begin{array}{l}80.55 \\
80.37 \\
83.82 \\
81.58\end{array}$ & $\begin{array}{l}79.60 \\
79.72 \\
83.19 \\
80.84\end{array}$ \\
\hline Yorkshire-Spotted & $\begin{array}{l}\text { Duroc } \\
\text { Duroc-Landrace } \\
\text { Landrace } \\
\text { Average }\end{array}$ & $\begin{array}{l}80.45 \\
70.94 \\
78.91 \\
76.77\end{array}$ & $\begin{array}{l}78.07 \\
68.75 \\
76.80 \\
74.55\end{array}$ \\
\hline Landrace-Spotted & $\begin{array}{l}\text { Duroc } \\
\text { Duroc-Yorkshire } \\
\text { Yorkshire } \\
\text { Average }\end{array}$ & $\begin{array}{l}82.16 \\
80.44 \\
82.93 \\
81.84\end{array}$ & $\begin{array}{l}79.66 \\
78.74 \\
81.20 \\
79.84\end{array}$ \\
\hline $\begin{array}{l}\text { Standard error } \\
\text { (range) }\end{array}$ & $\begin{array}{l}\text { Individual breed groups } \\
\text { Averages }\end{array}$ & $\begin{array}{l}3.14-4.30 \\
2.23-2.71\end{array}$ & $\begin{array}{l}3.19-4.36 \\
2.26-2.74\end{array}$ \\
\hline
\end{tabular}


1975; Fahmy and Holtmann, 1977; Conlon and Kennedy, 1978; Anderson et al., 1981). Wilson et al. (1977) did observe an increase in number of embryos $30 \mathrm{~d}$ postbreeding for litters sired by crossbred boars, but the differences were not significant.

The choices involving the breed or crossbred group of the boars and the sow herd were both important, but for different reasons. The sow's breeding had some impact upon the size and weight of the litter but, with these types of crossbred sows, had little effect on conception rate. The breeding of the boar had little effect on the litter traits but influenced the conception rate, particularly when crossbred boars were compared with purebred boars. When the traits were combined so that crosses could be compared for litter weight at $42 \mathrm{~d}$ per sow exposed during an 8-wk breeding period, the two best crosses were Duroc-Landrace females bred to Yorkshire-Spotted boars and Yorkshire-Landrace females bred to Duroc-Spotted boars (89.23 and $88.63 \mathrm{~kg}$, respectively). These were also the two best crosses for litter weight at $21 \mathrm{~d}$ per sow exposed (40.78 and $40.68 \mathrm{~kg}$, respectively). There was a small advantage for crossbred-sired litters for both litter weight per sow exposed during the 8 -wk breeding season at $21(2.77 \%)$ and $42 \mathrm{~d}(1.27 \%)$. For sows exposed to first service the crossbred boar advantage was larger (14.7 and $13.3 \%$ at 21 and $42 \mathrm{~d}$, respectively).

These results provide direct evidence favoring the use of crossbred boars for commercial producers who breed a fixed number of females to young boars during a specified breeding season. They should expect a higher conception rate, particularly on first service. This will reduce the length of time before a gilt begins production and will reduce the length of time a sow is out of production between litters. Producers who maintain a gilt pool and have continuous farrowing should also benefit from using crossbred boars. They would not have to keep as many females in the gilt pool and still could keep their farrowing facilities full. These results do not provide any direct evidence concerning the use of more mature crossbred boars. Further studies should be conducted to determine if older crossbred boars continue to be more aggressive breeders or will remain in service longer, but if the advantages re- ported here are just the result of crossbred boars reaching sexual maturity earlier, there may be little advantage for crossbred boars if older boars are used.

\section{Literature Cited}

Anderson, J. H., H. I. Sellers and K. A. Barber. 1981. Reproductive performance of purebred and crossbred boars in commercial herds. J. Anim. Sci. 53(Suppl. 1): 133.

Conlon, P. D. and B. W. Kennedy. 1978. A comparison of crossbred and purebred boars for semen and reproductive characteristics. Can. J. Anim. Sci. 58:63.

Drewry, K. J. 1980. Sow productivity traits of crossbred sows. J. Anim. Sci. 50:242.

Fahmy, M. H. and W. B. Holtmann. 1977. Evaluation of three- and four-breed cross litters and pigs sired by purebred and crossbred boars. Anim. Prod. 24:261.

Fent, R. 1980. Influence of breed on testicular and endocrine function of puberal boars. M.S. Thesis. Oklahoma State Univ., Stillwater.

Harvey, W. R. 1982a. Least-squares analysis of discrete data. J. Anim. Sci. 54: 1067.

Harvey, W. R. $1982 \mathrm{~b}$. Mixed model capabilities of LSML76. J. Anim. Sci. 54:1279.

Hauser, E. R., G. E. Dickerson and D. T. Mayer. 1952. Reproductive development of crossbred and inbred boars. Missouri Agr. Exp. Sta. Res. Bull. 503.

Holtmann, W. B., M. R. Fahmy, T. M. MacIntyre and J. E, Moxley. 1975. Evaluation of female reproductive performance of 28 one-way crosses produced from eight breeds of swine. Anim. Prod. 21:199.

Hutchens, L. K, R L. Hintz and R. K. Johnson. 1982. Breed comparisons for age and weight at puberty in gilts. J. Anim. Sci. 55:60.

Johnson, R. K. 1980 . Heterosis and breed effects in swine. North Central Regional Pub. No. 262.

Kuhlers, D. L., S. B. Jungst, R. L. Edwards and J. A. Little. 1981. Comparison of specific crosses from Landrace, Duroc-Landrace and YorkshireLandrace sows. J. Anim. Sci. 53:40.

Kuhlers, D. L., S. B. Jungst, R. L. Edwards and J. A. Little. 1982. Comparisons of specific crosses from Duroc-Landrace, Spot-Landrace and Hampshire-Landrace sows. J. Anim. Sci. $55: 236$.

Lishman, W. B., W. C. Smith and M. Bichard. 1975. The comparative performance of purebred and crossbred boars in commercial pig production. Anim. Prod. 21:69.

Neely, S. D., B. H. Johnson and O. W. Robison. 1980. Heterosis estimates for measures of reproductive traits in crossbred boars. J. Anim. Sei. $51: 1070$.

Wilson, E. R., R. K. Johnson and R. P. Wettemann. 1977. Reproductive and testicular characteristics of purebred and crossbred boars. J. Anim. Sci. 44: 939. 